\title{
AKTIVISME DAN KAPITALISME DIGITAL: KONSTRUKSI BRANDING WARUNG KOPI MELALUI INSTAGRAM
}

\author{
Nabilla Nailur Rohmah ${ }^{\mathbf{1}}$ dan Shuri Mariasih Gietty Tambunan ${ }^{2}$ \\ ${ }^{1}$ Departemen Susastra, Fakultas Ilmu Pengetahuan Budaya, Universitas Indonesia \\ Email: nabilla.nailur@ui.ac.id \\ 2 Departemen Susastra, Fakultas Ilmu Pengetahuan Budaya, Universitas Indonesia \\ Email: shuri.mariasih@ui.ac.id
}

Masuk :15-04-2019, revisi: 12-09-2019, diterima untuk diterbitkan : 12-09-2019

\begin{abstract}
ABSTRAK
Berkembangnya teknologi digital dan demokratisasi di berbagai aspek kehidupan di Indonesia saat ini telah mendorong pesatnya gerakan sosial, budaya maupun politik di ruang publik. Salah satunya adalah bermunculannya warung kopi sebagai tempat berkumpul, menyuarakan pendapat, dan mendiskusikan berbagai permasalahan. Studi kasus penelitian ini adalah bisnis warung kopi yang mengasosiasikan diri dengan aktivisme dan seiring dengan penciptaan tren konsumsi dan gaya hidup kelas menengah urban. Fenomena tersebut tidak terlepas dari wacana third wave coffeee yang sedang menarik perhatian dan minat para aktivis untuk menghubungkan specialty coffee dengan pemberdayaan petani dan pengembangan bisnis skala mikro. Dalam masyarakat jejaring (the network society) saat ini, banyak di antara para pengelola bisnis warung kopi menggunakan media sosial sebagai sarana untuk membangun jejaring dan promosi. Media sosial menjadi salah satu media promosi yang strategis karena menawarkan efektifitas dalam menyampaikan gagasan aktivisme serta kepentingan bisnis sekaligus. Artikel ini membahas bagaimana bisnis warung kopi mengasosiasikan diri dengan dunia aktivisme dan memosisikan branding mereka melalui media sosial Instagram. Penelitian ini menggunakan pendekatan Cultural Studies, dan dilakukan dengan menggabungkan metode digital etnografi dan metode analisis tekstual. Tiga akun Instagram, @kopikultur, @kopikintamani dan @kedaikopi_kalimetro, dianalisis untuk mendiskusikan kompleksitas konstruksi branding warung kopi dalam kaitannya dengan isu identitas gerakan, transformasi sosial, dan kepentingan ekonomi. Hasil penelitian menunjukkan bahwa konstruksi branding warung kopi di Instagram memuat adanya upaya penciptaan transformasi sosial melalui aktivisme konsumen serta artikulasi identitas gerakan dalam rangka akumulasi kapital sosial dan simbolik.
\end{abstract}

Kata Kunci: konstruksi branding, Instagram, third wave coffee, aktivisme konsumen, artikulasi identitas

\section{ABSTRACT}

The development of digital technology and democratization of various aspects of life in Indonesia today has encouraged rapid social, cultural and political movements in public forum. One such example is the emergence of coffee shops as a place to gather, voice opinions, and discuss various issues. The case study of this research is a coffee shop businesses associating themselves with activism and going hand in hand with the consumption trends and lifestyle of the urban middle class. This phenomenon is inseparable from the discourse of third wave coffee which is attracting the attention and interest of activists to connect specialty coffee with the empowerment of farmers and micro-scale business development. In current network society, many coffee shop business managers use social media as a mean to build networks and for promotions. Social media is a strategic promotion media for its effectiveness in conveying activism ideas along with business interests. This article discusses how coffee shop businesses associate themselves with activism and position their branding through Instagram. This study used Cultural Studies approach, and was carried out by combining digital ethnographic method and textual analysis method. Three Instagram accounts, @kopikultur, @kopikintamani and @kedaikopi_kalimetro, were analyzed to discuss the complexity of the coffee shop branding construction in relation to issues of movement identity, social transformation, and economic interests. The result showed that the construction of a coffee shop branding on Instagram carries along an effort to create social transformation through consumer activism as well as the articulation of movement identity in the context of the accumulation of social and symbolic capital.

Keywords: branding construction, Instagram, third wave coffee, consumer activism, identity articulation 


\section{PENDAHULUAN}

\section{Latar Belakang}

Berkembangnya masyarakat jejaring (the network society) sebagai bagian dari gejala budaya kontemporer di era digital telah mendorong lahirnya ruang publik untuk berdiskusi dan mengeluarkan pendapat di berbagai aspek kehidupan sehari-hari. Proses demokratisasi ini membuka ruang-ruang baru bagi masyarakat atau munculnya pemaknaan ulang terhadap ruang publik yang sudah ada. Salah satunya adalah warung kopi yang sebenarnya sudah menjadi bagian dari praktik budaya, terutama di Eropa, sejak abad ke-18 (Habermas et. al., 1991). Warung kopi, kafe, dan salon telah digunakan sebagai salah satu situs ruang publik borjuis dalam konteks Eropa. Dalam konteks Indonesia saat ini, penciptaan ruang publik di warung kopi 'modern' atau kafe berkembang pesat sejak dekade 2000-an. Pada dasarnya budaya minum kopi sudah menjadi bagian dari keseharian masyarakat di Indonesia sejak pertama kali kopi dibawa VOC pada akhir abad ke-16 (Gumulya \& Helmi, 2017). Berkembangnya warung kopi sebagai ruang aktivisme sejak dekade 2000-an ini dapat dipahami sebagai euforia kebebasan berekspresi pasca runtuhnya kekuasan rezim Orde Baru yang selama lebih dari tiga dekade mengontrol penuh segala aspek kehidupan sosial, ekonomi, politik, dan budaya. Kondisi ini menjadi kesempatan bagi aktivisme, baik yang dimotori oleh mahasiswa, CSOs, atau kelompok sosial lainnya untuk hadir di ruang publik menciptakan wacana-wacana diskursif ataupun praktik intervensi sosial. Di sisi lain, kebebasan berekspresi dan menyatakan pendapat secara luas mendorong berkembangnya budaya nongkrong atau berkumpul dan bersantai di warung kopi di kalangan aktivis. Warung kopi menjadi ruang sosial untuk berdiskusi dan menyampaikan kritik, baik dalam obrolan-obrolan kecil maupun forum yang lebih besar, formal, dan terorganisir.

Berkembangnya budaya nongkrong dan berdiskusi di warung kopi di kalangan aktivis mendorong lahir dan berkembangnya bisnis-bisnis warung kopi yang mengasosiasikan diri dengan gerakan sosial. Salah satu wacana yang berkembang adalah bahwa warung kopi sebagai situs gerakan tidak hanya menjadi ruang konsolidasi, namun juga secara praktis bekontribusi menciptakan transformasi dan pemberdayaan sosial. Selain itu, wacana third wave coffeee yang berkembang di Indonesia sejak dekade 2010-an melahirkan tren aktivisme melalui produksi dan konsumsi kopi. Third wave coffee adalah budaya menikmati kopi yang menitik beratkan pada konstruksi otentisitas kopi dan proses pengelolaan serta penyajian secara artisan, yang tidak mengutamakan kuantitas produksi (Fischer, 2017; Manzo, 2014). Dalam tren ini, penikmat kopi merasa perlu untuk mengenal asal muasal biji kopi yang mereka seduh dan memahami proses pengelolaan hingga penyajian yang berkelas (Knox, 2016). Budaya ini telah mengubah tren industri kopi berskala besar dan mendorong bermunculannya kedai kopi independen, eksplorasi cita rasa dan eksotisme biji kopi, serta inovasi dalam pengelolaan dan penyajian kopi (Ottencoffee.co.id, 2015; tempo.co.id, 2018). Wacana third wave coffee melahirkan gagasan bahwa pemberdayaan petani dapat dilakukan melalui proses produksi dan konsumsi kopi dengan cara yang tepat.

Beberapa penelitian terdahulu telah mengeksplorasi hubungan antara warung kopi dengan aktifitas gerakan. Erman (2016) menunjukkan bahwa warung kopi dapat berfungsi sebagai ruang pembentukan komunitas, solidaritas, dan saluran politik resistensi dalam memperjuangkan keadilan. Di sisi lain, Misbah (2018) meneliti warung kopi sebagai ruang dan media bagi gerakan propagasi sufisme. Jeffrey et al. (2017) mengeksplorasi peran warung kopi dalam menumbuhkan subjektivitas politik pemuda. Penelitian-penelitian tersebut menggali bagaimana warung kopi dapat memfasiltasi agenda sosial dan politik, namun belum ada yang membongkar 
bagaimana warung kopi mengkonstruksi branding dan menciptakan bentuk-bentuk intervensi sosial melalui praktik ekonomi yang mereka lakukan.

\section{Rumusan Masalah}

Dalam penelitian ini, pembahasan tentang konstruksi branding warung kopi dalam media sosial seperti Instagram tidak terlepas dari pembahasan tentang wacana third wave coffeee yang sedang berkembang di Indonesia. Penelitian ini akan mengeksplorasi bagaimana kompleksitas konstruksi branding warung kopi berhubungan dengan wacana third wave coffeee dalam menciptakan gerakan atau inisiatif lokal dan transformasi sosial, serta mengusahakan kepentingan ekonomi. Penggunaan media sosial untuk penciptaan branding komunitas sudah digunakan oleh perusahan-perusahaan untuk mengembangkan bisnisnya (Muniz dan O'guinn, 2001 dalam Kaplan dan Haenlein, 2010). Media sosial Instagram memainkan peran penting dalam membentuk strategi bisnis berbasis rumah tangga dan membantu penciptaan branding mereka (Latiff dan Safiee, 2015). Artikel ini secara spesifik mengkaji konstruksi branding warung kopi yang mengasosiasikan diri dengan aktivisme dalam akun Instagram @kopikultur, @kopikintamani @kedaikopi_kalimetro. Penelitian ini berfokus untuk mengetahui bagaimana konstruksi branding tersebut memberikan makna dan signifikasi bagi gerakan dan inisiatif lokal, bisnis, dan publik luas.

\section{METODE PENELITIAN}

Analisis dalam penelitian ini dilakukan untuk melihat konstruksi branding melalui pendekatan Cultural Studies yang menekankan pentingnya melakukan penelitian multidisiplin dapat membongkar latar belakang ideologis fenomena budaya ini. Berkembangnya praktik dalam dunia digital dan masyarakat jejaring mendorong penggunaan media sosial sebagai salah satu ruang untuk melakukan observasi dan penelitian mengenai fenomena-fenomena sosial dan budaya yang sedang terjadi. Penelitian mengenai praktik budaya seperti warung kopi tidak lagi hanya bisa mengandalkan metode pengumpulan dan analisis data lapangan seperti observasi dan wawancara dalam etnografi. Penelitian harus juga menggunakan metode lain, seperti digital etnografi yang memperlakukan Instagram sebagai sebuah field (Van Maanen, 2011) dalam menginterpretasikan representasi tekstual, visual, dan audio-visual.

approach, but the conventional ethnographic practices that they stand for begin to shift. In digital ethnography, we are often in mediated contact with participants rather than in direct presence.(Pink, et.al. 2016, 21).

Dalam penelitian ini, Instagram dilihat sebagai media penelitian dan sumber data. Instagram dapat menyediakan sumber data secara luas dari para pengguna online, dan sebagai ruang observasi yang dapat menjelaskan dinamika dan perubahan yang sedang berlangsung dalam masyarakat hari ini (Toscano, 2017).

Adapun penelitian ini dilakukan dengan menggabungkan metode digital etnografi dan metode analisis tekstual. Representasi branding pada akun Instagram @kopikultur,@kopikintamani,@kedaikopi_kalimetro dilihat berdasarkan teks visual, audio visual serta keterangan gambar atau caption yang menyertainya. Pemaknaan atas unggahanunggahan ketiga akun Instagram tersebut juga dilihat berdasarkan posisinya sebagai aktor dalam dunia gerakan di Indonesia. Data yang diperolah dari unggahan-unggahan tersebut 
diinterpretasikan dan dianalisis secara kontekstual untuk memahami konstruksi kaitannya dengan diskursus yang lebih luas. Pengumpulan dan kategorisasi dalam penelitian ini berasal dari unggahan-unggahan pada tahun 2018. Dalam jangka waktu tersebut, akun @kedaikopi_kalimetro pernah memperbaharui keseluruhan unggahan dengan menghapus semua kiriman-kiriman yang telah lama dan mengganti secara keseluruhan. Data yang digunakan dalam penelitian ini mencakup unggahan-unggahan lama dan baru yang dapat diakses selama tahun 2018.

\section{HASIL DAN PEMBAHASAN}

\section{Mendorong Tranformasi Sosial melalui Konsumsi?}

Salah satu isu sentral dalam konstruksi branding warung kopi aktivis adalah dorongan untuk turut serta berpartisipasi menciptakan transformasi sosial melalui konsumsi kopi. Ketiga akun @kopikultur, @kopikintamani@kedaikopi_kalimetro menampilkan dorongan tersebut dengan menampilkan gambar, video, serta keterangan tertulis yang merepresentasikan kedekatan dengan petani kopi. Akun @kopikultur menampilkan representasi kedekatan tersebut dengan menampilkan potret-potret petani yang sedang memanen kopi. Selain itu ditampilkan pula foto pengelola kedai Kopi Kultur berkunjung dan turut serta dalam pengelolaan pasca panen dengan petani. Akun @kedaikopi_kalimetro juga menampilkan hal yang hampir serupa. Video dan foto dalam kiriman akun ini menampilakn aktivitas panen petani kopi, kunjungan pengelola Kedaikopi Kalimetro ke petani, serta potret-potret biji kopi yang masih belum dipetik dari pohonnya. Beberapa kiriman menampilkan aktivitas di warung kopi yang tidak berhubungan sama sekali dengan petani, tetapi diberikan keterangan tertulis yang menggambarkan keberpihakan terhadap petani kopi.

Kiriman akun@kopikulturdan@kedaikopi_kalimetro membangun citra hubungan yang egaliter antara pengelola warung kopi dengan petani. Dalam akun @kopikultur, petani disebut sebagai mitra dan dihadirkan sebagai pakar yang menguasai pengetahuan dan ketrampilan dalam menanam kopi. Pengelolaan pasca panen yang mereka lakukan bersama para petani dihadirkan sebagai sebuah kerjasama dalam menghasilkan biji kopi yang berkualitas. Akun ini memprofil dirinya sebagai "Coffeee with true story" yang menceritakan kisah-kisah dibalik pengelolaan kopi oleh petani mitra mereka. Dalam akun @kedaikopi_kalimetro, hubungan dengan petani digambarkan sebagai hubungan kekeluargaan. Kunjungan pengelola warung kopi ke petani kopi ditampilkan sebagai kegiatan silaturahmi. Dengan jargon "mari ngopi iling petani" (setelah minum kopi ingat petani) dan "merawat rasa iling petani" (merawat rasa mengingat petani), akun ini mencitrakan adanya hubungan emosional antara pengelola warung kopi dengan petani. 


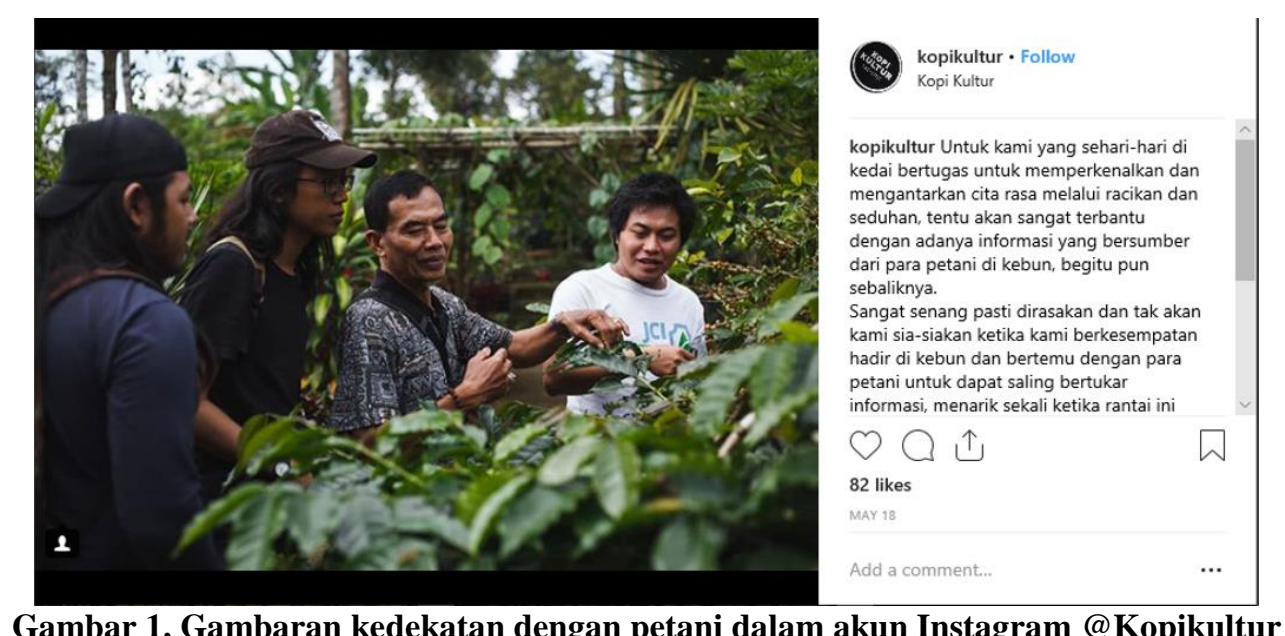

Representasi kedekatan dengan petani dalam kiriman @kopikultur dan @kedaikopi_kalimetro membentuk hubungan simbolik antara konsumen dengan petani kopi. Melalui hubungan simbolik tersebut, pengelola warung kopi mentransformasikan produk menjadi sistem tanda keberpihakan dengan menghidupkan representasi nilai-nilai pemberdayaan, penguatan, dan keadilan ekonomi di benak konsumen. Pemaknaan tersebut tidak terlepas dari konteks sosial yang melatar belakangi kedua warung kopi tersebut. Kopi Kultur adalah sebuah unit usaha yang dibangun dengan gagasan wirausahawan sosial yang berusaha menggabungkan aktivitas bisnis dengan agenda gerakan sosial.Warung kopi ini merupakan bagian dari Rumah Sanur, yaitu sebuah pusat komunitas lokal di Bali yang ditujukan bagi para seniman, pekerja kreatif, pemikir, serta pegiat wirausaha sosial. Sementara Kedaikopi Kalimetro merupakan salah satu unit usaha yang dibangun oleh Komunitas Kalimetro, yaitu sebuah komunitas gerakan sosial progresif di kota Malang. Sehingga dapat dipahami bahwa penggunaan makna simbolik dan citraan aktivisme dalam promosi warung kopi tersebut tidak dimaknai sebagai citraan manipulatif; melainkan sebagai bentuk komodifikasi dari semangat dan nilai-nilai aktivisme dan keberpihakan mereka.

Sementara itu, akun@kopikintamani menampilkan kiriman-kiriman yang merepresentasikan hubungan yang lebih hierarkis dengan petani kopi. Dengan memprofil dirinya sebagai aktivis dan petani pada bagian bio, akun ini banyak menampilkan potret aktifitas bertani dan aktifitas pengelolaan biji kopi oleh pemilik warung kopi. Potret-potret aktivitas pemrosesan biji kopi dari perawatan tanaman, panen, jemur, hingga roasting merepresentasikan keahlian pemilik warung kopi dalam mengelola produknya. Proses pengelolaan bersama para petani desa dimaknai sebagai aktivitas pemberdayaan. Sementara itu, proses pengelolaan yang melibatkan para petani juga dimaknai sebagai aktivitas menjual jasa kepada pemilik warung kopi. 


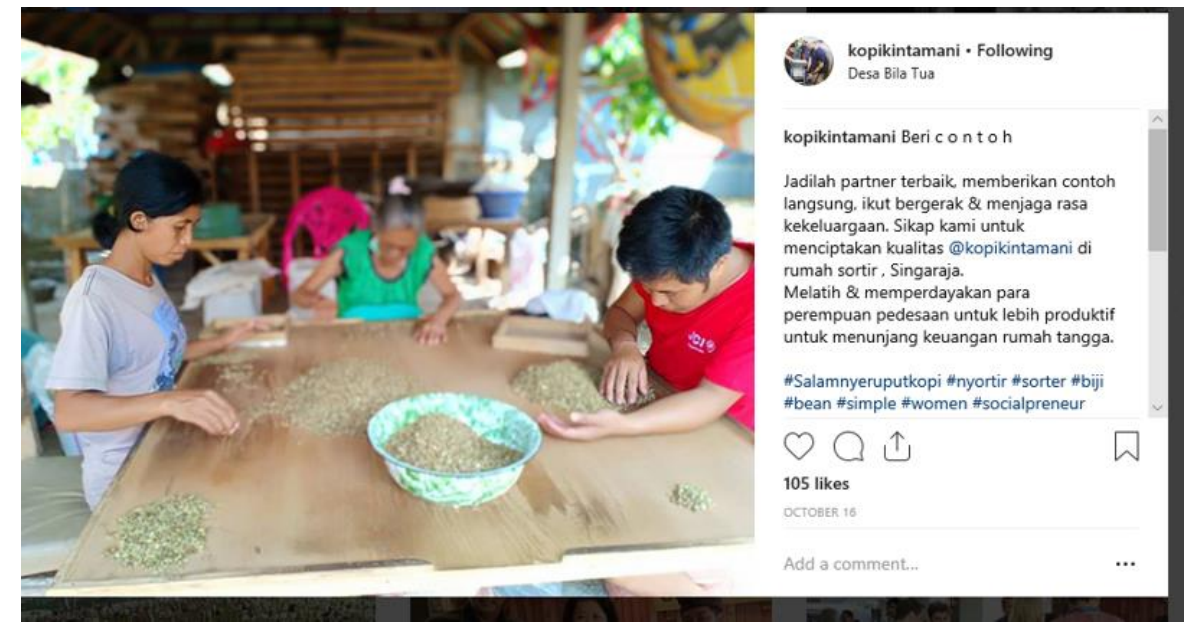

Gambar 2. Gambaran hubungan dengan petani dalam akun Instagram @ kopikintamani

Kiriman-kiriman yang merepresentasikan kedekatan dengan petani kopi dan menampilkan eksplorasi proses pengelolaan kopi menunjukkan adanya pengaruh wacana third wave coffee dalam konstruksi branding @kopikultur, @kedaikopi_kalimetro, @kopikintamani. Hal tersebut juga didukung oleh menu kopi-kopi pilihan dan berkelas yang ditampilkan dalam akun-akun Instagram tersebut. Third wave coffee adalah era ketika kopi tidak sebatas diperlakukan sebagai komoditas, melainkan telah menjelma gaya hidup yang berorientasi kepada kopi-kopi berkualitas, bercita rasa unik, dan memiliki identitas berdasarkan daerah asal (single origin). Gagasan third wave coffee menuntut pengelola bisnis untuk tidak hanya menyajikan minuman kopi, tetapi juga menyajikan cerita dan informasi dibalik proses pengelolaan kopi hingga sampai kepada konsumen. Meskipun demikian wacana third wave coffee ini menjadi hal yang sangat problematis. Tren specialty coffee yang menuntut pengelolaan ketat dan panjang serta teknologi pemrosesan yang mahal melahirkan elitisme baru. Ryan dan During menyatakan:

Third wave could be expected to gain broad appeal among other social classes related to goods associated with elite status; it may also elicit disdain among certain social classes, depending on their condition, perception, and association. More to the point, third wave coffeee is the product of the complex connectivity in the modern global economy (Ryan dan During, 1997 dalam Tucker, 2011)

Kiriman-kiriman yang memuat proses-proses pegelolaan kopi serta interaksi antara pengelola warung kopi dengan petani dimaknai sebagai upaya untuk mendekatkan konsumen dengan petani sebagai produsen. Hal ini dapat dipahami sebagai salah satu cara untuk "menerobos dinding alienasi" yang secara inheren melekat pada komoditi. Duncombe (2012) menyebutkan bahwa usaha untuk menciptakan sistem produksi, pertukaran, dan konsumsi yang less-alienating adalah salah satu bentuk aktivisme konsumen. Dalam hal ini, kiriman-kiriman @kopikultur, @kedaikopi_kalimetro, @kopikintamani dapat dimengerti sebagai startegi de-fetisisasi dalam membangun aktivisme konsumen oleh pengelola warung kopi. Namun, cerita dan informasi yang dtampilkan dalam pemrosesan biji kopi dalam akun Instagram kopikultur, @kedaikopi_kalimetro, @kopikintamani tidak memberikan gambaran kontekstual tentang kondisi sosial, ekonomi, politik, dan kultural yang melatarbelakangi produksi biji kopi tersebut. Pengaruh wacana third wave coffee dapat dilihat dari kecenderungan romantisasi dalam cerita dan informasi yang mengkonstruksi branding mereka. Dalam hal ini, kegagalan menampilakan aspek sosio-politik-hitoris dalam proses produksi membuat promosi hanya menawarkan sosiofantasi atas identitas yang dikehendaki konsumen saja (Duncombe, 2012). 
Menggunakan konsumerisme sebagai strategi untuk menciptakan bentuk penjualan alternatif menjadi suatu hal yang problematis. Di satu sisi, konsumer aktivisme memiliki potensi subversif sebagai salah satu bentuk gerakan anti kapitalisme yang membuat terobosan baru dalam menciptakan hubungan-hubungan sosial dan hubungan produksi yang berkeadilan; namun di sisi lain ia sejalan dengan prinsip-prinsip neoliberalisme dalam hal kebebasan, pilihan, budaya konsumerisme, dan subjektivitas homo ekonomikus (Rice, 2013). Dalam hal ini, dapat dilihat bahwa terdapat persamaan karakteristik antara konstruksi branding dalam akun Instragram @kopikultur, @kedaikopi_kalimetro, @kopikintamani dengan konsumer aktivisme. Keduanya menunjukkan bagaimana sistem produksi alternatif selalu bersifat ambivalen. Di satu sisi branding yang mereka bangun merepresentasikan keberpihakan yang memberikan keuntungan dan penguatan tehadap petani yang menjadi mitranya. Namun branding yang dikonstruksi dalam akun-akun tersebut menunjukkan bagaimana strategi bisnis mereka menciptakan konsumsi gaya hidup dan elitisme. Selain itu konstruksi branding dalam akun @kopikintamani yang merepresentasikan hubungan kerja dengan petani juga menunjukkan bagaimana bisnis yang dijalankan mereproduksi sistem produksi kapitalis.

Konstruksi branding dalam akun Instagram @kopikultur, @kedaikopi_kalimetro, @kopikintamani menunjukkan bahwa aktivitas branding yang mereka lakukan menampilkan cerita dan informasi yang berhubungan dengan petani dan pemrosesan biji kopi dengan kecenderungan romantisasi. Konstruksi branding dalam akun tersebut tidak menampilkan konteks sosial, ekonomi, dan kultural di balik produksi biji kopi. Namun demikian, kirimankiriman tersebut dapat menjadi contoh bentuk penguatan yang dapat dilakukan dengan tanpa merubah struktur pasar.

\section{Gerakan atau Inisiatif Lokal sebagai Artikulasi Identitas}

Konstruksi branding warung kopi aktivis tidak terlepas dari identifikasinya dengan dengan gerakan sosial. Terdapat perbedaan yang cukup signifikan antara @ kopikultur, @kedaikopi_kalimetro, dan @kopikintamani dalam mengidentifikasikan dirinya dengan dunia gerakan. Akun@kopikultur mengasosiasikan dirinya dengan gerakan kewirausahaan sosial yang terhubung dengan para seniman dan pekerja kreatif dari kelas menengah atas. Secara visual, kiriman akun ini didominasi oleh foto-foto aktivitas pemrosesan dan penyajian kopi serta kegiatan berkumpul yang merepresentasikan selera kelas menengah atas. Jenis-jenis acara yang diadakan, dipublikasikan, dan didokumentasikan dalam akun ini juga merujuk pada gaya hidup kelas atas. Akun ini tidak banyak mempublikasikan kegiatan diskusi, kecuali sebuah kiriman yang mendeskripsikan aktivittas kerja professional sambil bersantai di Kopikultur. Sebagian besar publikasi acara dan poster yang dikirim dalam akun Instagram warung kopi ini menggunakan bahasa Inggris. Selain itu, terdapat beberapa kiriman yang mendokumentasikan aktivitas cupping dan penampilan musik jazz.

Sementara itu, akun @kedaikopi_kalimetro mengasosiasikan dirinya dengan gerakan sosial progresif yang merangkul semua pihak dari berbagai lapisan kelas sosial. Representasi karakter gerakan yang bersifat konfrontatif dihadirkan melalui publikasi beberapa poster dan dokumentasi acara diskusi yang megangkat tema-tema perlawanan. Namun, akun ini juga manampilkan fasilitasi terhadap acara-acara dengan tema yang lebih popoler dalam kirimannya, seperti konser amal, pertemuan organisasi mahasiswa, diskusi LSM dengan anggota masyarakat, pertemuan pegiat media, dan kelas seni. Sementara itu, kiriman foto-foto dalam akun ini didominasi oleh pengambilan latar tempat yang sederhada dengan dinding bambu, tempat duduk lesehan, dan bangunan semi permanen. Foto-foto dan keterangan tertulis yang dikirim dalam akun ini merepresentasikan karakter gerakan kerakyatan yang bersifat guyub dan komunal. 
Akun@kopikintamani menampilkan identitasnya sebagai gerakan pemberdayaan petani yang memiliki jaringan berskala global dan bersifat konformis terhadap pemerintah dan pemangku kekuasaan. Representasi sikap politik tersebut dihadirkan melalui foto-foto dokumentasi yang menunjukkan partisipasi warung Kopi Kintamani dalam mendukung acara pertemuan World Bank dan IMF di Bali. Selain itu, akun ini juga banyak menampilkan kunjungan sejumlah pejabat pemerintah pusat ke warung dan kebun kopi. Potret kedekatan pemilik warung kopi dengan para pengusaha nasional dan kepala daerah direpresentasikan dalam beberapa kiriman yang memuat foto pertemuan mereka. Sementara itu, citra sebagai warung kopi berskala global ditampilkan melalui kiriman-kiriman yang menunjukkan kunjungan wisatawan berkulit putih ke kebun dan warung kopi, dokumentasi pertemuan pegiat kopi Internasional, hingga partisipasi warung Kopi Kintamani dalam acara kebudayaan di luar negeri.

Kiriman-kiriman pada ketiga akun warung kopi tersebut pada dasarnya tidak hanya merepresentasikan identitas bisnis dan aktivisme mereka, tetapi juga dapat dipahami sebagai bentuk konstruksi dan atikulasi identitas. Identitas bukanlah sesuatu yang bersifat esensial, melainkan dikonstruksi secara terus-menerus yang melibatkan proses artikulasi. Hall mendefinisikan artikulasi sebagai proses menciptakan hubungan-hubungan yang membentuk kesatuan antara elemen-elemen yang berbeda dalam suatu kondisi tertentu untuk menciptakan makna baru (Hall dalam Slack, 2005). Dalam sebuah proses artikulasi, hubungan yang tercipta bersifat fleksibel, tidak terikat, bersifat spesifik historis, dan dibentuk untuk mengekspresikan atau merepresentasikan makna dalam sebuah struktur dominasi dan subordinasi (Hall dalam Slack, 2005; Barker, 2002).

Artikulasi identitas dalam kiriman-kiraman akun warung kopi tersebut dapat dipahami dengan melihat perbedaan representasi dari tiap-tiap unggahan yang pada dasarnya tidak berkaitan atau bahkan saling kontradiktif antara yang satu dengan yang lain. Dalam akun @ kopikultur hal ini dapat dilihat bagaimana kiriman-kiriman tentang petani yang direpresentasikan dalam kesederhanaan dan penuh dedikasi tidak memiliki keterkaitan makna - atau bahkan kontradiktif dengan tampilan gaya hidup menengah atas yang ditawarkan. Hubungan yang tercipta antara elemen-elemen tersebut diartikulasikan@ @ kopikultur untuk menghadirkan makna bahwa mereka tidak hanya berkelas, tetapi juga visioner dan memiliki wawasan sosial. Proses penciptaan makna yang demikian menjadikan Kopi Kultur bukan hanya warung kopi yang melayani pelanggan, tetapi juga memiliki daya tawar tersendiri di hadapan pelanggan dan lingkaran sosialnya. Artikulasi dengan demikian merupakan bentuk penempatan diri dalam suatu hubungan dan konteks tertentu (Hall dalam Grossberg, 2005).

Demikian halnya akun @kedaikopi_kalimetro dan@kopikintamani menghubungkan berbagai elemen yang berbeda dalam mempromosikan usaha warung kopinya. Akun @ kedaikopi_kalimetro menghubungkan gagasan perlawanan, keluwesan dalam berjejaring, seni mengelola kopi, serta berbagai aktualisasi aktivitas seni untuk mengkonstruksi identitasnya. Konstruksi tersebut menunjukkan bahwa bisnis warung kopi ini tidak hanya menjadi ruang akumulasi profit, tetapi juga ruang akumulasi modal sosial dan modal simbolik di lingkaran aktivis gerakan sosial progresif. Sementara itu, akun @kopikintamani menghubungkan konektivitas global, pembauran dengan petani lokal, profesionalisme kerja, hingga ekspresiekpsresi personal pemilik warung kopi dalam berbagai kegiatan rekreasi. Konstruksi tersebut berusaha menunjukkan bahwa Kopi Kintamani mampu melebur dengan berbagai pihak dan mampu menempatkan diri dalam berbagai situasi sosial. 
Konstruksi branding ketiga warung kopi melalui akun instagram @kopikultur @kedaikopi_kalimetro@kopikintamani pada dasarnya tidak hanya ditujukan untuk akumulasi kapital ekonomi, tetapi juga akumulasi kapital sosial dan kapital simbolik di lingkaran gerakan masing-masing. Konten-konten yang dikirim dalam akun Instagram ketiga warung kopi tersebut telah memiliki audiens khusus dari kelompok-kelompok sosial tertentu. Penggabungan beberapa elemen yang berbeda dalam mengkonstruksi identitas warung kopi tersebut menjadi ruang untuk membangun posisi di lingkaran gerakan dan target konsumen masing-masing.

\section{KESIMPULAN DAN SARAN}

Runtuhnya kekuasaan rezim Orde Baru menjadi momentum bagi berkembangnya ruang publik dalam kehidupan sosial dan politik di Indonesia. Suatu ketepatan bahwa di era ini teknologi informasi berkembang dengan pesat. Internet dan media sosial menjadi bagian kehidupan yang tak terpisahkan. Kondisi ini memberikan kesempatan bagi berkembangnya ruang publik di dunia nyata maupun dunia maya. Keduanya melebur dalam sebuah hubungan yang kompleks, dan menciptakan dialog diskursif dalam masyarakat kita hari ini. Dalam penelitian ini, ditunjukkan bagaimana keduanya bertemu dan saling mengkonstruksi satu sama lain. Penelitian tentang konstruksi branding warung kopi dalam akun @kopikultur @kedaikopi_kalimetro @kopikintamani menunjukkan bagaimana konstruksi branding dalam media sosial tidak hanya menjadi kegiatan promosi warung kopi saja; tetapi juga dapat menjadi ruang untuk mengembangkan bentuk-bentuk aktivisme konsumen, artikulasi identitas, dan akumulasi kapital sosial dan simbolik. Perbedaan-perbedaan representasi identitas akun Instagram @kopikultur @kedaikopi_kalimetro @kopikintamani menunjukkan bahwa kapitalisme digital yang difasilitasi oleh media sosial dapat mereproduksi berbagai wacana dan melebur dalam ideologi yang berbeda-beda.

\section{Ucapan Terima Kasih}

Peneliti mengucapkan terima kasih kepada partisipan yang telah bersedia berkontribusi untuk penelitian ini, serta pihak-pihak yang telah membantu dalam penyusunan artikel ini.

\section{REFERENSI}

Barker, C. (2002). Making sense of cultural studies: Central problems and critical debates. Sage.

Duncombe, S. (2012). It stands on its head: Commodity fetishism, consumer activism, and the strategic use of fantasy. Culture and Organization, 18(5), 359-375.

Erman, E. (2016). Dinamika komunitas warung kopi dan politik resistensi di Pulau Belitung. Masyarakat Indonesia, 40(1), 89-107.

Fischer, E. F. (2017). Quality and inequality: Taste, value, and power in the third wave coffee market (No. 17/4). MPIfG Discussion Paper.

Grossberg, L. (2005). On Postmodernism and Articulation: An Interview With Stuart Hall. Dalam David Morley dan Kuan Hsing Chen (Eds). Stuart Hall: Critical Dialogue in Cultural Studies (pp. 113-129). Routledge.

Gumulya, D., \& Helmi, I. S. (2017). Kajian Budaya Minum Kopi Indonesia. Jurnal Dimensi Seni Rupa dan Desain, 13(2), 153-172. 
Habermas, J., Habermas, J., \& Mccarthy, T. (1991). The structural transformation of the public sphere: An inquiry into a category of bourgeois society. MIT press.

Jeffrey, A., Staeheli, L. A., Buire, C., \& Čelebičić, V. (2017). Drinking coffeee, rehearsing civility, making subjects. Political Geography.

Kaplan, A. M., \& Haenlein, M. (2010). Users of the world, unite! The challenges and opportunities of Social Media. Business horizons, 53(1), 59-68.

Knox, A. (2016). Coffee nation: an analysis of jobs in A ustralia's café industry. Asia Pacific Journal of Human Resources, 54(3), 369-387.

Latiff, Z. A., \& Safiee, N. A. S. (2015). New Business Set Up for Branding Strategies on Social Media-Instagram. Procedia Computer Science, 72, 13-23.

Majalah Otten Coffee. (6 Agustus 2015). Sejarah "First, Second, and Third Wave Coffeee". Diakses pada 1 November 2018 dari https://majalah.ottencoffeee.co.id/sejarah-firstsecond-and-third wave-coffeee

Manzo, J. (2014). Machines, people, and social interaction in "third-wave" coffeehouses. Journal of Arts and Humanities, 3(8), 1-12.

Misbah, A. "Potret Lanskap Harmoni Dalam Proses Propagasi Sufisme Di Warung Kopi Yogyakarta." Harmoni 17, no. 1 (2018): 88-104.

Slack, J. D. (2005). The theory and method of articulation in cultural studies. Dalam David Morley dan Kuan Hsing Chen (Eds). Stuart Hall: Critical Dialogue in Cultural Studies (pp. 113-129). London: Routledge.

Pink, S. et.al. (2016). Digital Ethnography: Principles and Practice, London: Sage.

Rice, J. S. (2013). Homo economicus and consumer activist subjectivity: anti-capitalist activism through alternative trade. New political economy, 18(6), 845-861.

Tempo.co (November 2018). Pamor Ramuan Biji Gilingan. Diakses pada 6 November dari https://investigasi.tempo.co/edisi-khusus-kopi/pamor-ramuanbiji-gilingan/index.html

Toscano, P. (2017). Instagram-City: New Media, and the Social Perception of Public Spaces. Visual Anthropology, 30(3), 275-286.

Tucker, C. M. (2011). Coffeee culture: local experiences, global connections. Routledge.

Van Maanen, J. (2011). Tales of the field: On writing ethnography. Chichago: University of Chicago Press. 